TAPROBANICA, ISSN 1800-427X. November, 2021. Vol. 10, No. 02: pp. 128-130.

(C) Research Center for Climate Change and Department of Biology, Faculty of Mathematics \& Natural Sciences, University of Indonesia, Depok 16424, INDONESIA.

http://www.taprobanica.org

https://doi.org/10.47605/tapro.v10i2.263

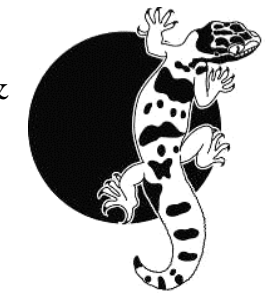

\section{Copulatory behavior of Knuckles pygmy lizard (Cophotis dumbara)}

Nearly one in every five species of reptiles in the world is threatened with extinction and thus is conservation dependent (Meiri et al. 2018). In order to develop effective and targeted species conservation strategies, detailed information on their distribution, systematics and ecology are necessary (Roll et al. 2017). Information such as the natural history and in-situ reproductive behaviors would be crucial for highly threatened species that require ex-situ conservation measures. Agamid lizards are a major component of the global reptile diversity and a significant number are threatened due to habitat loss and other threats such as smuggling (Roll et al. 2017).

Among the 21 agamid lizard species in Sri Lanka, the endemic genus Cophotis is represented by the two species, $C$. ceylanica Peters, 1861 and $C$. dumbara Samarawickrama et al., 2006. Due to their small size (SVL of 50$60 \mathrm{~mm}$ ) they are commonly known as pygmy lizards and are in high demand for the global pet trade (Janssen \& de Silva 2019). Cophotis dumbara is an arboreal lizard restricted to the montane cloud forests of the Knuckles Mountain range in Sri Lanka (Manamendra-Arachchi et al. 2006, Samarawickrama et al. 2006). This endemic small lizard is categorized as a Critically Endangered (CR) species in the IUCN Red List (MOE 2012, Gibson et al. 2020). Although the species is regularly seen among the cloud forest vegetation above 1,200 m a.s.l., virtually nothing is known about its natural history and ecology. Here, we report the first observation on its copulatory behavior in natural conditions.

The observation was made in the Riverstone area $(7.526278 \mathrm{~N}, 80.738612 \mathrm{E})$ on the Mathale - Illukkumbura Road (B274). Although this area has already been fragmented and exposed to regular human interferences due to this road, the area still maintains some of the unique habitat characteristics of mountain cloud forests. The vegetation in agamid habitats at Riverstone is well documented by Manamendra-Arachchi et al. (2006) and Amarasinghe et al. (2014a,b). The observations here were made from a distance of 3-5 m using Kowa Prominar BD42-10XD $(10 \times 42)$, Vanguard Endeavor ED $(10.5 \times 45)$, Swarovski SLC $(8 \times 42)$, and Swarovski EL $(8.5 \times 42)$ binoculars. Further, the behavior was photo-documented using Canon EOS R, EOS 7D Mark II, EOS 5D Mark III digital cameras fixed with Canon 16-35 mm, Canon $500 \mathrm{~mm}$, and Sigma $180 \mathrm{~mm}$ macro lenses respectively.

A mature female (total length $\sim 150 \mathrm{~mm}$ ) was observed at $0855 \mathrm{~h}$ on 2 July 2020. The weather was sunny with a cool breeze, the sunlight shaded by clouds from time to time. At the time of observation, the lizard had palegreen body coloration with irregular white and dark bands. The tail had about 5-6 distinct dark bands. It had a fat belly region, so seemed gravid. Initially, the lizard was observed $3 \mathrm{~m}$ above the ground on a slightly diagonal twig of the shrub Austroeupatorium inulifolium (family: Asteraceae). Later, it started to move up towards a nearby Symplocos obtusa (family: Symplocaceae) tree. After climbing about $1 \mathrm{~m}$ from its original position, it descends again about half a meter towards its original position. After a few clumsy attempts spanning 30 minutes, it climbed to the $S$. obtusa tree up to $\sim 5$ $\mathrm{m}$ above the ground.

A second individual, a mature male almost the same size as the female, was observed $\sim 30$ $\mathrm{cm}$ away from her last position. It had a similar coloration, but with a much more prominent ebony-black color from the head region to the fore-limbs. This male had a distinct white upper lip band up to the shoulder area and a distinct white transverse stripe in between the eyes on the dorsal head. It had distinct nuchal spines and its gular sac turned bright reddish-orange when displaying to the female. The male's display for the female included rhythmic head bobbing behavior while flashing its colorful gular sac and nuchal spines (Fig. 1A). Also, the male arched 
his back and violently whipped his tail from side to side to get the attention of the female. Consequently, the female started to ascend slowly towards the male.

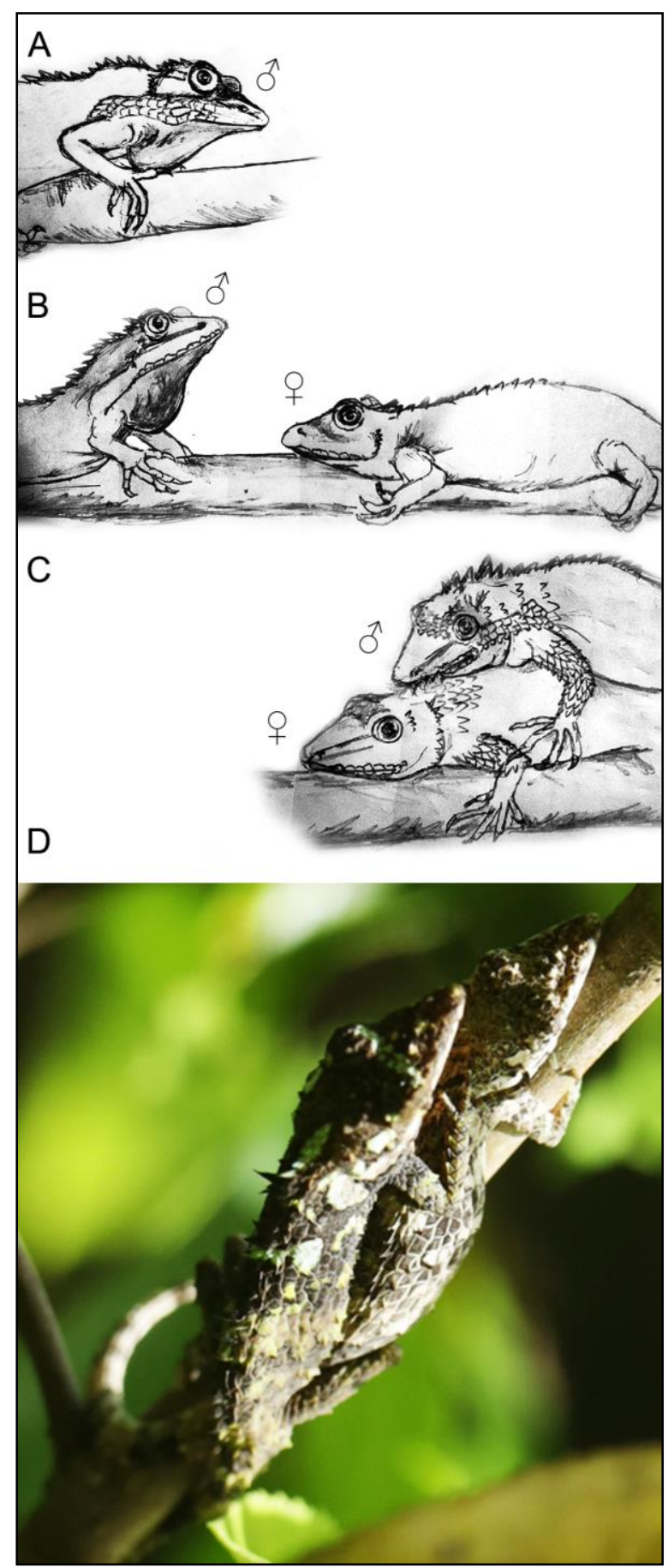

Figure 1. Cophotis dumbara (A) male displaying the gular sac, (B) male and female facing off, (C) male subduing female while biting her nuchal spines, and (D) copulation; (C) Photo: U.S.B. Hettige

Once they were close to each other, the couple positioned themselves facing opposite directions on the tree branch (Fig. 1B). Then the male rotated to the same direction in which the female was positioned. Then the male climbed onto the female in the mounting position (Fig. 1C). Here, the male continuously rubbed the female using his body and tail. The female stayed almost motionlessly, only waving her tail sideways.

Then the male fine-positioned itself on the female's back and bit her nuchal spines (Fig. 1C), aggressively pressed her towards the branch and started to copulate. The copulation lasted for 2 minutes (Fig. 1D). During the entire duration of copulation, the male subdued the female on the branch. The male started to move away from the female once the copulation was over.

After moving half a meter away from the copulation site, the male again displayed its gular sac. The same female then moved towards the male, and copulation was repeated once more, again lasting 2 minutes $(0859-0901 \mathrm{~h})$. After the second copulation, the female moved away from the male while the male rested motionlessly.

After the female disappeared from its sight, the male followed and displayed the gular sac again. It subdued and pressed her towards the branch as previously described and copulated for a third time, lasting for 3 minutes (0910-0913 h). During all three copulations, the male displayed much violent behavior while the female stayed calm except for rapid movements of the tail.

Once the third copulation was over, the female moved away from male towards the end of the thin branch and remained there until the male moved away out of sight. The bright colors of the male's gular sac gradually faded while it moved away. Around $0943 \mathrm{~h}$ the pair was well apart from each other and the observations were terminated.

The various courtship and mating behaviors typically known among agamid lizards; neck bite, courtship approach, courtship display, female acceptance (Patankar et al. 2013) were observed. The aggressive forceful behavior of the male pressing the female towards the tree branch resembles the behavior of Lake Eyre dragon (Ctenophorus maculosus) males pressing females to the ground prior to intromit when rejected or longer copulation period when rejected (Olsson 1995). This observation reports that regardless of the female possibly being gravid, the male successfully copulated three times. Previous studies have found that multiple copulations benefit males in yielding more offspring (Olsson 1995). Males copulate for 
longer periods with females that have recently mated with other males and males having larger sperm supplies copulate for longer periods (Olsson 2001). Thus, the multiple copulations of a male here with a seemingly gravid female could be explained.

\section{Acknowledgments}

We thank the Young Zoologists' Association of Sri Lanka, Bird \& Wildlife Team (Pvt.) Ltd., D. Chandranimal (YZA) for the support given in the identification of flora in the study area. Also, we thank I.H. Vitanage (YZA) for providing literature, K. Ukuwela (Rajarata University of Sri Lanka) for valuable comments on an earlier draft. D. Warakagoda (YZA, BWT), I. Harishchandra (YZA), and B.H.M.H.S.B. Katugaha (YZA) are acknowledged for their support in various ways.

\section{Literature cited}

Amarasinghe, A.A.T., D.M.S.S. Karunarathna, and J. Fujinuma (2014a). A new Calotes species from Sri Lanka with a redescription of Calotes liolepis Boulenger, 1885. Herpetologica, 70(3): 323-338.

Amarasinghe, A.A.T., D.M.S.S. Karunarathna, J. Hallermann et al. (2014b). A new species of the genus Calotes (Squamata: Agamidae) from high elevations of the Knuckles Massif of Sri Lanka. Zootaxa, 3785 (1): 59-78.

Gibson, C., A. de Silva, M.F. Tognelli, and S. Karunarathna (eds.) 2020. Assess to Plan: Conservation Action Planning for the Snakes and Lizards of Sri Lanka. IUCN Conservation Planning Specialist Group, Apple Valley, Minnesota: 79pp.

Janssen, J. and A. de Silva, (2019). The presence of protected reptiles from Sri Lanka in international commercial trade. TRAFFIC Bulletin, 31 (01): 9-15.

Manamendra-Arachchi, K., A. de Silva, and T. Amarasinghe (2006). Description of a second species of Cophotis (Reptilia: Agamidae) from the highlands of Sri Lanka. Lyriocephalus, 6 (Supp. 1): 1-8.
Meiri, S., A.M. Bauer, A. Allison et al. (2018). Extinct, obscure or imaginary: the lizard species with the smallest ranges. Diversity \& Distributions, 24(2): 262-273.

MOE (2012). The national Red List 2012 of Sri Lanka: Conservation status of the fauna and flora. Ministry of Environment, Colombo: 477pp.

Olsson, M. (1995). Forced copulation and costly female resistance behavior in the Lake Eyre dragon, Ctenophorus maculosus. Herpetologica, 51(1): 19-24.

Olsson, M. (2001). 'Voyeurism' prolongs copulation in the dragon lizard Ctenophorus fordi. Behavioral Ecology \& Sociobiology, 50(4): 378-381.

Patankar, P., I. Desai, J.N. Trivedi, and S. Balakrishnan (2013). Ethogram of courtship and mating behaviour of Sitana cf. ponticeriana (Reptilia: Draconinae: Agamidae) in India. Taprobanica, 5(1): 4450.

Peters, W. (1861). Eine neue gattnug (sic) von Eidechsen, Cophotis ceylanica, aus Ceylon vor. Monatsberichte der Koniglichen Preussischen Akademie der Wissenschaften zu Berlin: 1103-1105.

Roll, U., A. Feldman, M. Novosolov et al. (2017). The global distribution of tetrapods reveals a need for targeted reptile conservation. Nature Ecology \& Evolution, 1(11): 1677-1682.

Samarawickrama, V.A.M.P.K., K.B. Ranawana, D.R.N.S. Rajapaksha et al. (2006). A New Species of the Genus Cophotis (Squamata: Agamidae) from Sri Lanka. Russian Journal of Herpatology, 13(3): 207-214.

Submitted: 1 Aug. 2021, Accepted: 26 Oct. 2021 Section Editor: Thasun Amarasinghe

H.D.C. Soysa ${ }^{1,2,3}$, U.S.B. Hettige ${ }^{1,2}$, M.G. Cooray $^{1,2}$ \& D.R. Vidanapathirane ${ }^{1,2}$,

${ }^{1}$ Young Zoologists' Association of Sri Lanka, National Zoological Gardens, Dehiwala, Sri Lanka

${ }^{2}$ Bird \& Wildlife Team (Pvt.) Ltd., No.39, Galawilawatte, Homagama, Sri Lanka

${ }^{3}$ E-mail: hdcsoysa@mail.com 